\title{
INTERFACIAL ADSORPTION EQUILIBRIUM OF VERSATIC ACID
}

\author{
KATSUTOSHI INOUE, HIRONORI AMANO AND IsSEI NAKAMORI \\ Department of Industrial Chemistry, Saga University, Saga 840
}

Precise and detailed information about the interfacial adsorption equilibrium is nearly indispensable for the analysis of extraction kinetics of metals by extractants of high interfacial activity, because it is considered that the complex-forming reactions take place at the interface between two immiscible liquids in these extraction systems ${ }^{8}$.

Accordingly, there have been some publications ${ }^{1,31}$ on the interfacial adsorption equilibrium of several kinds of hydroxyoximes such as LIX 65N, LIX 63 and SME 529. Several authors ${ }^{2,3,11,12)}$ also tried to find some correlations between the interfacial adsorption properties and the extraction rate for these extractants. Though many works ${ }^{4,9,10)}$ have been carried out on the interfacial properties of fatty acids from the standpoint of surface science, the reports on those of commercial carboxylic acids such as Versatic acid (Shell Chemical Co., Ltd.) and naphthenic acid have apparently not been published to date.

In the previous papers, the authors reported the aqueous solubility of Versatic $10^{5}$, a newly developed Versatic acid, and also reported the adsorption equilibrium of acetic acid at the interface between water and organic diluents such as $n$-hexane, cyclohexane and benzene ${ }^{6)}$.

In the present paper, the interfacial adsorption equilibrium of Versatic 10 between aqueous ammonium nitrate-ammonia mixture and $n$-hexane solution is reported.

\section{Experimental}

Interfacial tension was measured by drop-weight method at $30^{\circ} \mathrm{C}$ after a $n$-hexane solution of Versatic 10 of known concentration $\left(C_{\mathrm{B} 0}\right)$ reached equilibrium with aqueous ammonium nitrate-ammonia mixture, the ionic strength of which was kept constant.

The $\mathrm{pH}$ of the aqueous phase was varied with the change of ammount of ammonia added and was measured by $\mathrm{pH}$-meter. The concentration of Versatic 10 in the organic phase after equilibration $\left(C_{\mathrm{Borg} .}\right)$ was calculated from $C_{\mathrm{B} 0}$ and $\mathrm{pH}^{5)}$.

In Fig. 1, the experimental results are shown as the relationship between interfacial tension and $C_{\mathrm{Borg}}$. for

\footnotetext{
Received January 28, 1980 Correspondence concerning this article should be addressed to $\mathrm{K}$. Inoue. H. Amano is now with Toshiba Silicon Co., Ltd., Q'ta 373 .
}

various values of $\mathrm{pH}$.

\section{Discussion}

From the results of the previous paper ${ }^{5}$, the aqueous solubility of Versatic 10 is expressed as follows.

$$
\begin{aligned}
& \mathrm{H}_{2} \mathrm{R}_{\text {2org. }} \rightleftharpoons 2 \mathrm{HR}_{\text {aq. }} \quad K_{1} \\
& \mathrm{HR}_{\mathrm{aq}}, \rightleftharpoons \mathrm{H}_{\mathrm{aq} .}^{+}+\mathrm{R}_{\mathrm{aq} .}^{-} \quad K_{2}
\end{aligned}
$$

where

$$
\begin{aligned}
& K_{1}=C_{\mathrm{HR}_{\mathrm{R}}}^{2} / C_{\mathrm{H}_{2} \mathrm{R}_{2}}=9.6 \times 10^{-7} \mathrm{~mol} / l \\
& K_{2}=C_{\mathrm{H}+} C_{\mathrm{R}} / C_{\mathrm{HR}}=1.1 \times 10^{-6} \mathrm{~mol} / l
\end{aligned}
$$

It was assumed in this study that only $\mathrm{HR}$ and $\mathrm{R}^{-}$, the monomeric species of Versatic 10 and its anionic species, respectively, can be adsorped at the interface while $\mathrm{H}_{2} \mathrm{R}_{2}$, dimeric species of Versatic 10 , which is predominant in the organic phase, cannot be adsorbed. Based on Langmuir's monolayer adsorption model, adsorption of these species is expressed as follows.

$$
\begin{array}{ll}
\mathrm{HR}_{\mathrm{aq} .} \rightleftharpoons \mathrm{HR}_{\mathrm{ad} .} & K_{\mathrm{AHR}} \\
\mathrm{R}_{\mathrm{aq} .}^{-} \rightleftharpoons \mathrm{R}_{\mathrm{ad} .}^{-} & K_{\mathrm{AR}^{-}}
\end{array}
$$

where

$$
\begin{gathered}
K_{\mathrm{A} i}=\theta_{i} / S_{i}(1-\theta) \cdot C_{i} \quad\left(i=\mathrm{HR}, \mathrm{R}^{-}\right) \\
\theta=\theta_{\mathrm{HR}}+\theta_{\mathrm{R}^{-}}
\end{gathered}
$$

According to Gibbs' adsorption isotherm, the relation between interfacial tension and the concentration of adsorbed species is expressed for an ideal solution as follows.

$$
-d \gamma=\sum_{i} \Gamma_{i} d \mu_{i}=\mathrm{R} T \cdot \sum_{i}\left(\theta_{i} / S_{i}\right) \cdot d\left(\ln C_{i}\right)
$$

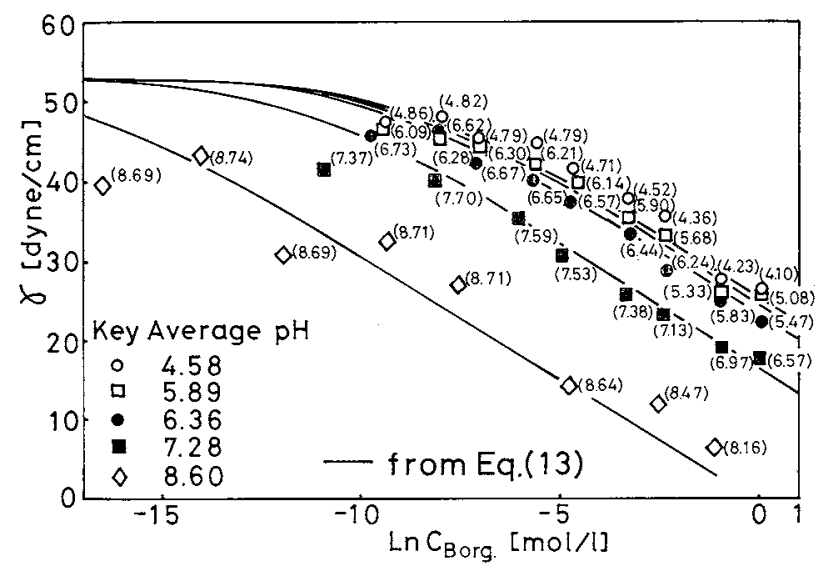

The numbers in parentheses denote $\mathrm{pH}$ after equilibration.

Fig. 1 Variation of interfacial tension by $\mathrm{C}_{\mathrm{Borg}}$. and $\mathrm{pH}$ 


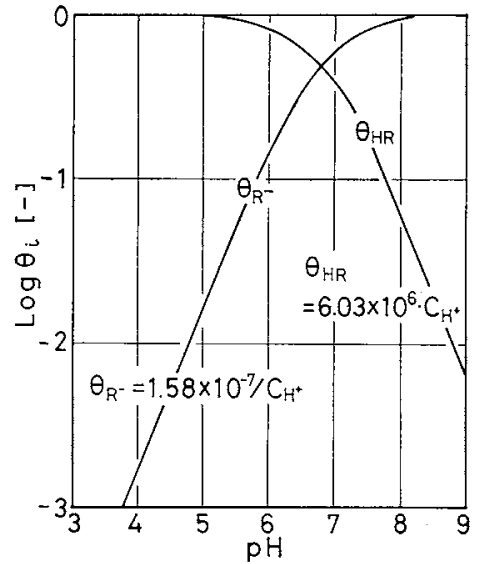

Fig. 2 Variation of fractional coverage of each component by $\mathrm{pH}$

If it is assumed that $S_{i}$, the interfacial area occupied by the $i$-th adsorbed species, is nearly equal to each other for each adsorbed species, i. e.

$$
S_{\mathrm{HR}} \simeq S_{\mathrm{R}^{-}}=S
$$

Equation (9) is reduced to Eq. (11) by integration using Eqs. (4), (7) and (8).

$$
\gamma=\gamma_{0}-\frac{\mathrm{R} T}{S} \cdot \ln \left\{1+\left(K_{\mathrm{AHR}}+K_{\mathrm{AR}-} K_{2} / C_{\mathrm{H}}{ }^{+}\right) \cdot S \cdot C_{\mathrm{HR}}\right\}
$$

Since it is considered that Versatic 10 exists as the dimeric species in such nonpolar diluent as $n$-hexane, $C_{\mathrm{HR}}$ is expressed by Eq. (12).

$$
C_{\mathrm{HR}}=\left(K_{1} C_{\mathrm{H}_{2} \mathrm{R}_{2}}\right)^{1 / 2} \simeq\left(K_{1} C_{\text {Borg. }} / 2\right)^{1 / 2}
$$

Therefore, Eq. (11) is rewritten as follows.

$$
\begin{aligned}
\gamma= & \gamma_{0}-(\mathrm{R} T / S) \\
& \times \ln \left\{1+\left(K_{\mathrm{AH} \mathrm{R}}+K_{\mathrm{AR}-}-K_{2} / C_{\mathrm{H}}+\right) \cdot S \cdot\left(K_{1} C_{\mathrm{Borg} .} / 2\right)^{1 / 2}\right\}
\end{aligned}
$$

The optimum values of $K_{\mathrm{AHR}}, K_{\mathrm{R}-}$ and $S$ which give the least standard deviation between experimental and calculated values expected from Eq. (13) were evaluated by Marquardt's nonlinear least square method $^{7)}$ as follows. $K_{\mathrm{AHR}}=2.8 \times 10^{-5} \mathrm{l} / \mathrm{cm}^{2}, K_{\mathrm{AR}}=$ $4.2 \times 10^{-6} \mathrm{l} / \mathrm{cm}^{2}, S=4.1 \times 10^{9} \mathrm{~cm}^{2} / \mathrm{mol}$.

The solid lines in Fig. 1 are the calculated results based on Eq. (13) using these values and the average $\mathrm{pH}$ values. The maximum deviations between the experimental and the calculated results are about $\pm 20 \%$ though some plotted points, especially those the average $\mathrm{pH}$ of which is 8.60 , apparently deviate much more from the theoretical lines since they were calculated using average $\mathrm{pH}$. It is concluded that the interfacial tension can be expressed well by Eq. (13).

Figure 2 shows the variations of $\theta_{\mathrm{HR}}$ and $\theta_{\mathrm{R}}-$ with $\mathrm{pH}$ calculated from Eqs. (7) and (8). The variation with $C_{\text {Borg. }}$ is negligibly small in the concentration range of $C_{\text {Borg. }}=0.1-1.0 \mathrm{~mol} / l$. From Fig. 2 , it is evident that

\begin{tabular}{|c|c|c|}
\hline \multicolumn{3}{|c|}{ Nomenclature } \\
\hline$C_{B}$ & $\begin{array}{l}=\text { total concentration of Versatic } 10 \text { in the } \\
\text { organic phase }\end{array}$ & {$[\mathrm{mol} / l]$} \\
\hline$C_{i}$ & $\begin{aligned}= & \text { concentration of } i \text {-th component } \\
& \left(i=\mathrm{H}^{+}, \mathrm{HR}, \mathrm{H}_{2} \mathrm{R}_{2}, \mathrm{R}^{-}\right)\end{aligned}$ & {$[\mathrm{mol} / /]$} \\
\hline HR & $=$ species of monomeric form of Versatic 1 & \\
\hline $\mathrm{H}_{2} \mathrm{R}_{2}$ & $=$ species of dimeric form of Versatic 10 & \\
\hline$K_{1}$ & $\begin{array}{l}=\text { partition constant of Versatic } 10 \text { into the } \\
\text { aqueous phase defined by Eq. (3) }\end{array}$ & {$[\mathrm{mol} / l]$} \\
\hline$K_{2}$ & $\begin{array}{l}=\text { dissociation constant of Versatic } 10 \text { in th } \\
\text { aqueous phase }\end{array}$ & he $[\mathrm{mol} / l]$ \\
\hline$K_{\mathrm{A} i}$ & $\begin{aligned}= & \text { interfacial adsorption equilibrium consta } \\
& \text { of } i \text {-th species }\left(i=\mathrm{HR}, \mathbf{R}^{-}\right)\end{aligned}$ & $\stackrel{\text { ant }}{\left[l / \mathrm{cm}^{2}\right]}$ \\
\hline $\mathrm{R}$ & $=$ gas constant $\quad[$ dyne $\cdot \mathrm{cm} / \mathrm{d}$ & $\mathrm{deg} \cdot \mathrm{mol}]$ \\
\hline $\mathbf{R}^{-}$ & $=$anionic species of Versatic 10 & \\
\hline$S$ & $\begin{aligned}= & \text { average interfacial area occupied by } \\
& \text { adsorbed species }\end{aligned}$ & $\left.\mathrm{cm}^{2} / \mathrm{mol}\right]$ \\
\hline$S_{i}$ & $\begin{aligned}= & \text { interfacial area occupied by } i \text {-th adsorbe } \\
& \text { species }\left(i=\mathrm{HR}, \mathrm{R}^{-}\right)\end{aligned}$ & $\left.\mathrm{cm}^{2} / \mathrm{mol}\right]$ \\
\hline$T$ & $=$ temperature & {$[\mathrm{K}]$} \\
\hline$\Gamma_{i}$ & $\begin{array}{l}=\text { moles of } i \text {-th adsorbed component per u } \\
\text { area }\end{array}$ & mol $\left.\mathrm{mol} / \mathrm{cm}^{2}\right]$ \\
\hline$f$ & $=$ interfacial tension & dyne $/ \mathrm{cm}]$ \\
\hline$\gamma_{0}$ & $=$ interfacial tension of diluent & dyne $/ \mathrm{cm}$ \\
\hline$\theta$ & $=$ total fractional coverage of interface & {$[-]$} \\
\hline$\theta_{i}$ & $\begin{array}{l}=\text { fractional coverage of interface by } i \text {-th } \\
\text { adsorbed species }\end{array}$ & $1-$ \\
\hline
\end{tabular}
in the region of $\mathrm{pH}<6, \mathrm{HR}$ is predominant at the interface and $\theta_{\mathrm{R}^{-}}$is in inverse proportion to $C_{\mathrm{H}}+$ while in the region of $\mathrm{pH}>7.5, \mathrm{R}^{-}$is predominant and $\theta_{\mathrm{HR}}$ is proportional to $C_{\mathrm{H}^{+}}$as expressed in this figure.

[dyne $\cdot \mathrm{cm} / \mathrm{mol}$ ]

$$
\begin{array}{ll}
\langle\text { Subscript }\rangle & \\
\text { aq. } & =\text { aqueous phase } \\
\text { ad. } & =\text { adsorbed } \\
\text { org. } & =\text { organic phase } \\
0 & =\text { initial }
\end{array}
$$

Literature Cited

1) Al-Diwan, T. A. B., M. A. Hughes and R. J. Whewell: J. Inorg. Nucl. Chem., 39, 1419 (1977).

2) Dobson, S. and A. J. van der Zeeuw: Chem. Ind., 175 (1976).

3) Flett, D. S.: Accounts of Chemical Research, 10, 99 (1977).

4) Goddard, E. D. and J. A. Ackilli: J. Colloid Sci., 18, 585 (1963).

5) Inoue, K., H. Amano, Y. Yayama and I. Nakamori: J. Chem. Eng. Japan, 13, 281 (1980).

6) Inoue, K. and Y. Bada: Kagaku Kogaku Ronbunshu, 4, 93 (1978).

7) Marquardt, D. W.: J. Soc. Ind. Appl. Math., 11, 431 (1963).

8) Nakashio, F., K. Inoue and K. Konđo: Kagaku Kögaku, 42, 182 (1978).

9) Peters, R. A.: Proc. Roy. Soc. London, Ser. A, 133, 140 (1931).

10) Spink, J. A.: J. Colloid Sci., 18, 512 (1963).

11) van der Zeeuw, A. J. and R. Kok: Proceedings of the International Solvent Extraction Conference 1977, p. 210, ed. by B. H. Lucas, G. M. Ritcey and H. W. Smith, Canadian Instn. Min. \& Metall., Ottawa (1979).

12) Yagodin, G. A., S. Yu. Ivakhno and V. V. Tarasov: Izv. Vyssh. Uchebn. Zaved., Khim. Khim. Tekhnol., 22, 692 (1979). 